\title{
The Economic Value and Valuation of Architectural Heritage
}

\author{
Svetlana Albu \\ Engineering, Law and Real Estate Valuation, Technical University of Moldova, Chisinau, Republic of Moldova \\ Email: svetlana.albu@emi.utm.md
}

How to cite this paper: Albu, S. (2021) The Economic Value and Valuation of Architectural Heritage. Journal of Building Construction and Planning Research, 9, 1-11. https://doi.org/10.4236/jbcpr.2021.91001

Received: November 25, 2020

Accepted: February 28, 2021

Published: March 3, 2021

Copyright $\odot 2021$ by author(s) and Scientific Research Publishing Inc. This work is licensed under the Creative Commons Attribution International License (CC BY 4.0).

http://creativecommons.org/licenses/by/4.0/

\begin{abstract}
This study reflects the authors' vision on the value of architectural heritage. The theories of value are examined, and the most explicit theory is identified from a practical point of view. From our perspective, the theory of entropic value is the most explicit theory from the point of view of detailing the reasoning process on the source of value, the value, and the measure of the value. The method of goods real value estimation is explained based on the analysis of the value creation mechanism, according to the entropic value theory. The analysis of the particularities of the architectural heritage from modern theory valuation perspective allowed authors to formulate methodological proposals for value estimation of real estate with cultural, architectural and historical value.
\end{abstract}

\section{Keywords}

Entropic Value, Approaches, Methods, Factors

\section{Introduction}

The importance, role, necessity and ways of preserving the architectural heritage for the future generations have been intensely discussed in recent decades. The value of cultural heritage, including architectural heritage is examined from different perspectives, and framed from different points of view. During the examination of the issue of architectural heritage value preservation, it was considered necessary to examine the theories of value, the mechanism of value creation, and the ways of value estimation.

\section{Value Theory}

The theories and concepts on the value described throughout history fall into the 
basic economic doctrines [1]-[9]:

- The liberal doctrine includes: the objective theory of value and price (A. Smith), the theory of value (D. Ricardo), contributions to the theory of value (J. B. Say);

- Socialist doctrine: the theory of "constituted value" (P. J. Proudhon), the conception of the essence of value (K. Marx);

- The neoclassical economics (marginalism): the conception of the essence of value (the Austrian school of economics, K. Menger), the conception of the essence of value (the Cambridge school of economics, A. Marshall);

- Post-neoclassical economics: the economics of value (P. Bran), the theory of integral value (S. Muravschi, A. Muravschi), the value theory of products with high energy capacity (Russian school A.V. Orlov, N.D. Batiushkov, etc.).

From our perspective the theory of entropic value is the most explicit theory from the point of view of detailing the reasoning process on the source of value, the value, and the measure of the value. This theory was developed by Paul Bran on the ground of A. Marshal's ideas.

Citing the father of that theory, "value is in economics what matter is in physics" [10]. We will point out the fundamental ideas of entropic value theory (EVT) emphasizing the value creation mechanisms and the nature of value. The value is created resulting from the triple change (production - consumption production) of the existing potential (natural, social, primary consumption within the enterprise) at the initial time. The required potential is processed in the initial production process, creating the necessary goods (economic potential, product type) for the subsequent intermediate consumption, during which the service (economic potential, services type) necessary in the next production process is created. For example, the tree (natural potential) processed with the lathe (primary consumption within the enterprise) by a trained man (social potential) is transformed into board, that is included in the next production process (door manufacturing). Consequently, the entropy theory of value considers that the value is created only when the commodity finds its consumer passing through the consumption process (for the subsequent production process).

Describing the nature of value, we will move from complex to simple. It should be mentioned that the production and consumption processes are quite complex and are focused on primary processes. The consumption process includes: the transfer or acquirement of inputs through distribution, exchange, direct takeover; the transformation of inputs through activities such as investments, stock building, purchasing and assimilating information, staff training; the preservation of the transformations results in the form of the elements of the structure and the capacity of this structure to provide services; the transfer of these consequences of the existence of the system to the interior of the respective system and to other systems (economic, society, environment).

The production process includes: the transfer by distribution, exchange, direct takeover of potential from its own structure or from society and environment; 
the transformation of inputs by company's technology; the preservation of the transformation results into products with a low entropy, above the inputs, as well as into waste with a high entropy; the transfer of products and waste to other systems and self-consumption [10] [11].

At the same time, the primary processes of transfer, transformation and conservation take place through the movement, combination, and modification of the basic components: substance, free energy, and information. In the production process the information is included in the substance with the help of energy. In the process of consumption, the energy is subordinated to information, using the material support of the system (substance).

Thus, according to this theory, the value of the good is created neither in the production process (as the labor theory of value argues), nor in the consumption process (according to the utility theory of value), it is the result of the combination of both processes consecutively. Low entropy is released during the creation of the product and its consumption in order to re-enter another production process, it represents the basic particles (information, substance, energy) decomposed, detached from the existing system and emitted in nature (in the form of various wastes).

\section{The Architectural Heritage Value from Entropic Value Theory Perspective}

According to EVT the real size of the value depends on the inputs from the initial moment $t_{0}$; the yields to the environment, society, and economy; and entropic losses related to the production-consumption-production chain.

Referring to the architectural heritage within the EVT model, the basic elements will be redefined. This change is conditioned by both the specific characteristics of real estate in general and by special characteristics of architectural heritage (real estate with historical, cultural, architectural value).

Thus, the initial time $t_{0}$ will correspond to the moment of recognition of the real estate as an object of cultural/architectural heritage. The potential existing at this moment includes natural potential (real estate itself), social potential (its recognition as an important real estate for future generations), economic potential (how to use/not use it currently).

The production process (time $t_{1}$ ) will include EVT transformation (restoration/conservation works of the construction), conservation (the object reaches the exploitable physical state), transfer (preparation of documents/commissioning certificate).

At the consumption stage (time $t_{2}$ ) the transformation will include the process of modification or adjustment to modern requirements of the real estate use (e.g. modernization of building utilities, transformation from housing to commercial building, museum, etc.) and the conservation-the real estate is adapted for that specific use and the general public is informed about the availability of the heritage site. 
At the production stage (moment $\mathrm{t}_{\mathrm{n}}$ ) the object of architectural heritage is included in the economic and/or cultural circuit (as a museum, included in tourist itineraries, used as an art gallery, etc.).

In other words, the potential preserved in the production process $t_{n}$ at the $P_{e n}$ level is transferred, in the form of money, to the consumer that is a service provider (private or public). This amount represents the real value of the architectural heritage.

As we can see, the value of the architectural heritage can be described in EVT framework, and it is subject to the same rules and processes.

\section{Valuation in EVT}

The valuation practice requires periodic adjustments of value estimation methods. Currently, the value estimation focuses on three approaches in valuation, three points of view that are reflected and can be explained by the theory of entropic value (Figure 1) [12] [13].

The cost approach is a comparative approach that for the purchase of a certain property considers the alternative of acquiring an equivalent, modern asset with the same utility. Without taking into account time, risk and inadequacy, the price a buyer would pay for the asset to be valued would not be higher than the cost of a modern equivalent.

In other words, the cost approach reflects the economic potential, in the form of a product, before it is included in the consumption process. Several natural factors will "draw out" the economic potential from the product during storage or transport; this destructive effect takes the form of physical wear and tear (degradation, friction, rot, aging, etc.). Other factors of social and economic nature will determine the moral depreciation of the potential contained in the products; competition from similar products as a utility, but cheaper, or with a higher

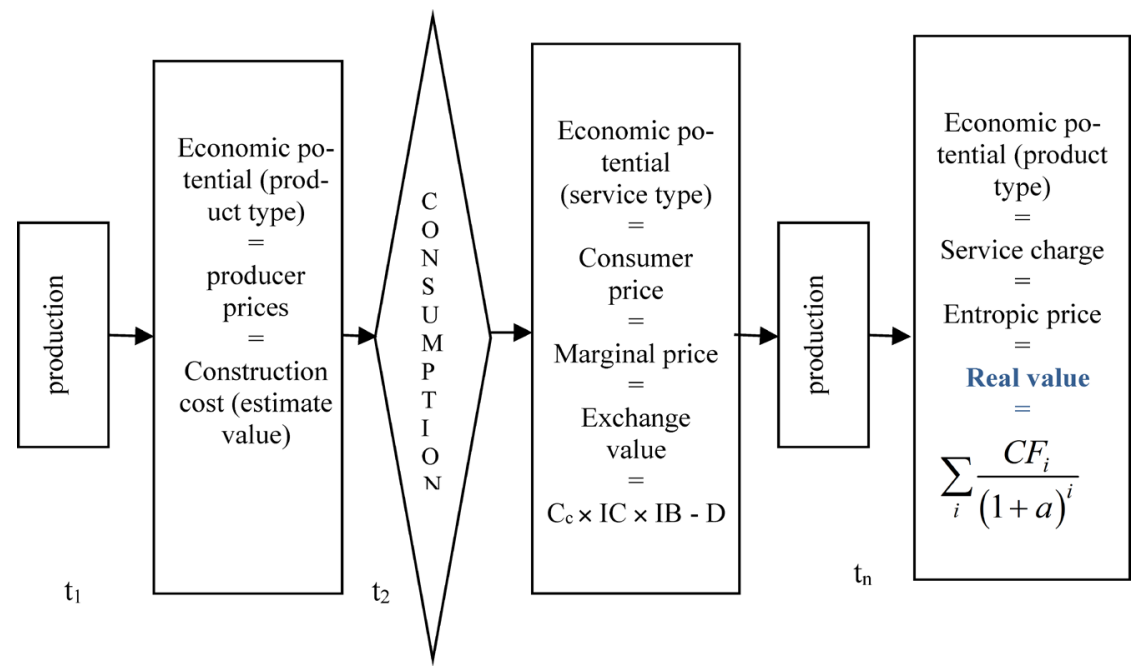

$\mathrm{C}_{\mathrm{c}}$ - cost of recreating a replica of the asset, $\mathrm{IC}$ - indirect costs, $\mathrm{IB}$ - investor benefit, $\mathrm{D}$ - accumulated depreciation, $\mathrm{CF}$ - cash flow, a-discount rate, i-period.

Figure 1. Estimation of value based on the theory of entropic value. 
efficiency in use, will partly nullify the potential preserved in the products.

From EVT's perspective, the produced economic potential does not represent the real value of the good. The valuation methodology does not recognize the cost of the good taking into account depreciation as a final value. It is corrected by specific costs of the consumption process (marketing expenses, advertising, insurance, transaction costs, etc., owner benefit—risk reward associated with the implementation of the investment project).

The sales comparison approach is a comparative approach that considers the sales of similar or substitutable properties and market information; it establishes an estimate of value based on comparison processes. In general, the valued property is compared to similar properties sold or traded on an open market.

According to the EVT value creation process, the value determined by the sales comparison method represents the economic potential of services type. During the examination of the quantitative, qualitative dimensions and reliability of the real estate in the dynamic state of consumption, we conclude that the subsequent economic potential is considered only at the level of comparison of the mode of use.

The income approach is a comparative approach that takes into account information about the income and expenses related to the valued property and estimates the value through the capitalization process. In general, the substitution principle shows that the income flow that produces the highest profit, corresponding to a certain level of risk, leads to the most probable size of value.

This approach fully corresponds to the requirements of EVT, the value represents the economic potential that can be gained from the consumption process at the time $t_{n}$.

Thus, we concluded that the real value of goods is estimated only by income methods. The application of the cost approach and the comparison approach allows to estimate the intermediate dimension of the value, that is the value of the good in the dynamic state of consumption.

\section{Valuation of the Architectural Heritage through EVT Perspective}

The next step is to examine the process of architectural heritage appraisal through EVT perspective. As it was shown in Figure 1, the real value of the goods is estimated only by income approach. The application of the cost approach and the comparison approach allows to estimate the intermediate dimension of the value, that is the value of the good in the dynamic state of consumption (Table 1).

Referring to the architectural heritage, both the value of the material component, as well as the value of the intangible component should be considered.

The value of the material component is created in the "production $t_{0}$ " process, the value of the intangible component is created in the "consumption $t_{1}$ " process; both being transferred to the next stage of "production $t_{n}$ " from which 
results the real value of the patrimony.

Consequently, the real value of the architectural heritage will be determined:

1) by discounted cash flow, this method can be applied if there is enough information,

2) as the sum of the real estate economic value and its cultural/architectural value (1):

$$
V=E V+C A V
$$

where:

$E V$-economic value of the real estate, $C A V$-cultural/architectural value of the real estate (intangible component).

The economic value of the real estate (Table 2) will be determined in accordance with its potential use (market or investment value), using the income approach methods. The cost approach should be used only when the object does not generate any revenue (net operating income is zero or negative). The valuation will be performed according to the current valuation methodology without

Table 1. Valuation methods according to the value creation stage.

\begin{tabular}{cccc}
\hline $\begin{array}{c}\text { The stages of the value } \\
\text { creation process }\end{array}$ & $\begin{array}{c}\text { Production } \\
\mathbf{t}_{0}\end{array}$ & Consumption $\mathbf{t}_{\mathbf{1}}$ & Production $\mathbf{t}_{\mathbf{n}}$ \\
\hline Economic potential & Producer price & Consumer price & Service charge \\
Value type & Estimated value & Marginal price & Entropic price \\
Valuation method & $\begin{array}{c}\text { Reproduction value } \\
\text { method }\end{array}$ & $\begin{array}{c}\text { Replacement value method } \\
\text { Comparison approach method }\end{array}$ & $\begin{array}{c}\text { Discounted cash } \\
\text { flow method }\end{array}$ \\
\hline
\end{tabular}

Table 2. Type of estimated value according to the valuation purpose.

\begin{tabular}{|c|c|}
\hline Value type & Valuation purpose \\
\hline \multicolumn{2}{|c|}{ Values as defined by International Valuation Standards } \\
\hline market & $\begin{array}{l}\text { - sale; } \\
\text { - reasoning financial decisions to increase the efficiency of real } \\
\text { estate use; } \\
\text { - for inclusion in the share capital. }\end{array}$ \\
\hline With the premise: current use & $\begin{array}{l}\text { - value to the current owner; } \\
\text { - reasoning financial decisions to increase the efficiency of real } \\
\text { estate use. }\end{array}$ \\
\hline investment & $\begin{array}{l}\text { - the investment decisions opportunity; financing real estate } \\
\text { development projects. }\end{array}$ \\
\hline fair & - privatization. \\
\hline \multirow[t]{2}{*}{ market rent } & - rent. \\
\hline & Other types of values \\
\hline Replacement (reproduction) & $\begin{array}{l}\text { - estimation of the damage; } \\
\text { estimation of the repair-rehabilitation works cost; determination } \\
\text { of the insurance amount or the refund amount of incurred } \\
\text { damage of the object with cultural/architectural value. }\end{array}$ \\
\hline
\end{tabular}


considering the existence of cultural/architectural value.

Special attention should be paid to the calculation of actual gross income (rent of real estate with $\mathrm{CAV}$ is higher as a rule), operating expenses (maintenance and repair costs of real estate with CAV are higher), the forecast period (often corresponds to the rehabilitation period, generally not less than 5 years), the value of the reversal-in the process of applying the income approach.

There are some specific features of the cost approach: accumulated depreciation (economic life is unlimited for such buildings), physical wear (which is significant, as buildings were built mainly in the $19^{\text {th }}$ and $20^{\text {th }}$ centuries), functional depreciation (which, as a rule, it is both functional and operational), economic depreciation (which in the case of objects with CAV depends on other factors compared to buildings without CAV).

The cultural-architectural value is determined as the surplus value generated by the existence of the defining elements of the architectural value, which can be grouped in 5 sets:

- the period of establishment,

- the author's solution,

- constructive embodiment,

- external factors,

- location, and others.

1) The influence of time on value.

First, this factor influences the number of heritage objectives: the older they are the less objectives with CAV there will be (however, the small amount influences the increase in value only indirectly). An indicative period of at least 40 50 years is recommended for considering a real estate with CAV.

Second, the time factor influences the function of the objective (the number of potential users decreases suddenly, which influences the reduction of value).

Third, this factor influences the existence of restored and reconstructed elements: the older they are, the more elements of the building have lost their original state. The number of items reproduced influences the decrease in value.

Fourth, this factor influences the status of the monument (as a rule, over time the status can increase, which indirectly increases the value).

Thus, time can influence the value of the architectural monument both in the direction of decrease, as well as towards its increase. Nevertheless, the value of the architectural heritage is not a function of time. It only allows the identification of the monument (the epoch, style, architect, etc.).

2) The influence of the author's solution on the value.

The architect and creator of the monument can be a recognized professional, which influences the value of the objective. Therefore the usefulness of the objective depends on "pioneering" solutions, analogies (copies) of which can be in a very large amount (for example Bartolomeo Francesco Rastrelli and Henri Louis Auguste Ricard de Montferrand worked very productively) or to be completely absent (for example individual constructive solutions of Le Corbusier's 
objects are unique, which is why they are highly appreciated).

The author's solution defines an object as an architectural monument and serves to determine the status of the object. The status of an object is associated with servitude and prestige, which affects the value of the object. It should be noted that there are unique monuments-buildings of unknown authors, where the structural embodiment influences the cost, not the author's decision.

The value of the architectural monument depends on the author's solution only when the monument is identified as a "pioneering solution".

3) The influence of constructive embodiment on value.

This factor correlates with the period of establishment and the author's solution, nonetheless the time factor presence is mandatory, regardless the absence or presence of information about the author. The exclusivity of the constructive embodiment defines the object as a monument and serves to determine the status of the object. The status of an object is associated with servitude and prestige, which affects the value of the object.

The modern construction technologies make it possible to reproduce copies of any monumental buildings, which is the basis for calculating the cost of replacement in the cost approach.

The constructive embodiment can be examined based on the following criteria:

- the uniqueness of the object;

- the role in urban planning;

- historical authenticity (it was kept in its original form; it underwent small changes; the original appearance was partially preserved, recreated, completely rebuilt);

- the facades and interiors decoration (completely preserved, partially lost, completely lost, initially absent);

- planning (completely preserved, partially modified, completely changed).

The value of the architectural monument depends on the constructive embodiment only when the object is identified as a "pioneering solution".

4) The influence of external factors on value.

External factors of influence are very diverse and cannot be included into a complete list. There are historical factors, cultural factors, religious factors, etc.

External factors of influence define the object as a monument and serve to determine the status of the object. The status of an object is associated with servitude and prestige, which affects the value of the object.

5) The influence of location on value.

The location influences the object classification as a monument, and directly affects the value of the objects.

There is a concept of historical location where all the buildings belong to the historical ensemble (e.g. Old Orhei, Moscow Kremlin).

The location for non-monumental properties determines the entrepreneurial profit or external depreciation for income-generating properties.

The cultural/architectural value can be estimated by the method of compara- 
tive analysis of sales using the following formula (2):

$$
V C=\Delta P=P_{a h}-P_{c p}
$$

where:

$P_{a h}$-the price of an architectural heritage site sold on the open market; $P_{c p}$-the price of a property comparable to the object of architectural heritage.

The method of secondary data can also be applied. According to Western analysts, CAV offers the property an increase in value of $30 \%-40 \%$, and experts from the Russian Federation have found an increase in value of $15 \%-30 \%$ for buildings with CAV compared to new buildings, e.g. type A offices [14].

This method can be used only in the case of compact areas that also include ordinary real estate and real estate with architectural value (e.g. the Historic Centre of Chisinau).

Russian scientists [14] [15] propose to estimate the CAV as the sum of the influences of two factors: servitude and prestige.

The prestige is examined from two perspectives: the prestige of owning a cultural/architectural monument and the prestige of the building location (Table 3). The location influences the value of the monument building, but the determining factor of the price is the presence of profit (actual or potential) of the investor, or the presence of economic depreciation (external) of the comparable buildings, which are not monuments. If the cultural/architectural monument building is located in the center of a large city, the building has a maximum value, and if it is located in an area with reduced accessibility, the value is minimum. The difference in value is determined by the investor's profit or external depreciation.

The estimated amount should be added at (in case of profit) or excluded from (in case of external depreciation) the reproduction or replacement value of the building.

The estimation of servitude, as a rule, reduces the value compared to objects without CAV, as a total or partial prohibition of interventions on constructions should be considered. The prestige, as a rule, increases the value of the patrimony with CAV.

Examining CAVs as intangible assets from the point of view of their formation within the enterprise, it should be noted the analogy of servitude with franchise,

Table 3. The most prestigious locations.

\begin{tabular}{|c|c|c|c|c|}
\hline \multirow{2}{*}{ The building use } & \multicolumn{4}{|c|}{ Location } \\
\hline & Big cities & Small cities & Villages & Mountain/seaside \\
\hline Offices & \multicolumn{2}{|c|}{ Centre } & Close to cities & $\mathrm{x}$ \\
\hline Trade & \multicolumn{2}{|c|}{ Centre and central highways } & \multicolumn{2}{|c|}{ Close to high traffic roads } \\
\hline Residential building & \multicolumn{2}{|c|}{ Centre } & Close to high traffic roads & $\mathrm{x}$ \\
\hline Multifunctional & \multicolumn{2}{|c|}{ Centre } & Close to high traffic roads & $\mathrm{x}$ \\
\hline Rural property & $\mathrm{x}$ & $\mathrm{x}$ & $\mathrm{x}$ & Far from cities \\
\hline
\end{tabular}


and prestige with goodwill ([15]. p. 139).

Therefore, the influence of servitude can be assessed by the methods of estimating the franchise, using, for example, the relief-from-royalty method, and the influence of prestige can be estimated by the excess earnings method or the expert method.

\section{Conclusions}

The research allows us to formulate the following conclusions:

- From our perspective, the theory of entropic value is the most explicit theory from the point of view of detailing the reasoning process on the source of value, the value, and the measure of the value.

- According to EVT, the value of the good is created neither in the production process (as the labor theory of value argues), nor in the consumption process (according to the utility theory of value). It is the result of the combination of both processes consecutively. Low entropy is released during the creation of the product and its consumption in order to re-enter another production process. It represents the basic particles (information, substance, energy) decomposed, detached from the existing system and emitted in nature (in the form of various wastes).

- The value of the architectural heritage can be described in terms of EVT. Respectively, it follows the same rules and processes.

- The real value of goods is estimated only by income methods. The application of the cost approach and the comparison approach allows to estimate the intermediate dimension of the value, in other words, the value of the good in the dynamic state of consumption.

- Consequently, the real value of the architectural heritage will be determined 1) by discounted cash flow, this method can be applied if there is enough information; 2) as the sum of the real estate economic value and its cultural/architectural value:

- The economic value of the real estate will be determined in accordance with its potential use (market or investment value), using the income approach methods. The cost approach should be used only when the object does not generate any revenue (net operating income is zero or negative). The valuation will be performed according to the current valuation methodology without considering the existence of cultural/architectural value.

- The cultural-architectural value (CAV) is determined as the surplus value generated by the existence of the defining elements of the architectural value. CAV can be estimated 1) by the method of comparative analysis of sales, or (2) by aggregating the influence of servitude (the relief-from-royalty method) and prestige (the excess earnings method).

\section{Acknowledgements}

The research was carried out within the project 20.80009.0807.34 Increasing the 
value of architectural heritage of R. Moldova.

\section{Conflicts of Interest}

The author declares no conflicts of interest regarding the publication of this paper.

\section{References}

[1] Albu, S. (2009) Valoarea patrimoniului. Problemele aprecierii și gestiunii. Universitatea Tehnica a Moldovei, Chisinau.

[2] Bran, P. (2002) Economica valorii. Editura ASE, Bucuresti.

[3] Bran, P. (2003) Finanțele întreprinderii. Gestiunea fenomenului microfinanciar. Ed. a 2-a, Editura Economica, Bucuresti.

[4] Albu, S. (2010) Teoria evaluării și teoria valorii entropice. Intellectus, 1, 33-41.

[5] Albu, S. and Albu, I. (2009) Evaluarea patrimoniului. Universitatea Tehnica a Moldovei, Chisinau.

[6] Яскевич, Е.Е. (2010) Теория и практика оценки зданий-памятников культурного наследия. https://cpcpa.ru/Publications/021/

[7] Касьяненко, Т.Г. and Краснова, А.Д. (2018) Стоимосная оценка зданийапмятников как недвижимых обьектов культурного наследия: монография. РГ-Пресс, Москва.

[8] Cojuhari A., Pogolşa A. and Pogolșa N. (2001) Doctrine economice moderne și contemporane. Acad. Intern. de Drept Economic, Curs de prelegeri. Ch.

[9] Smith, A. (1992) Avuția națiunilor. Vol. I, Universitas, Chișinău.

[10] Ricardo, D. (1993) Opere alese (în 2 vol). Vol. II, Universitas, Ch.

[11] Campagnolo, G. (2005) Carl Menger's “Money as Measure of Value”. History of Political Economy, 37, 245-261. https://doi.org/10.1215/00182702-37-2-245

[12] Bohm-Bawerk, E. (2002) Value, Cost and Marginal Utility. Translated by George Reisman. The Quarterly Journal of Austrian Economics, 5, 37-79. https://doi.org/10.1007/s12113-002-1031-6

[13] Орлов, А.В. (2004) Очерки общей экономической теории. Рационалистический подход. Изд-во СПбГПУ, СПб.

http://enbv.narod.ru/text/Econom/econom_theory/orlov_ocherk/index.html

[14] Орлов, А.В. (2005) Энергосодержащие продукты-материальная основа стоимости и ценности. Проблемы современной экономики. No. 3/4 (15/16). http://www.m-economy.ru/issue.php?nIssueNum=15\#16

[15] Lepak, D.P., Smith, K.G. and Susan, T.M. (2007) Value Creation and Value Capture: A Multilevel Perspective. Academy of Management Review, 32, 180-194. https://doi.org/10.5465/amr.2007.23464011 